\title{
Orbital apex syndrome secondary to sinonasal diffuse large B cell lymphoma: how rare is it?
}

See-Teng Tan ${ }^{1}$, Nor Akmar Binti Tak², Sudha A/P V.S Menon ${ }^{1}$

${ }^{1}$ Department of Ophthalmology, Hospital Tuanku Ja'afar Seremban, Malaysia; ${ }^{2}$ Department of Pathology, Hospital Tuanku Ja'afar Seremban, Malaysia

\section{Abstract}

A sinonasal lymphoma is an uncommon form of non-Hodgkin lymphoma (NHL), comprising only $1.5 \%$ of all lymphomas. Here, we report a rare case of primary sinonasal diffuse large $B$ cell lymphoma (DLBCL) found accompanying orbital apex syndrome. A 75-year-old Chinese man presented with progressively reduced visual acuity in the left eye for over 2 months. He also complained of frequent rhinorrhoea for the previous 4 months. Upon examination, his left eye was noted with poor vision with incomplete ptosis, periorbital fullness, and ophthalmoplegia. Laboratory findings were within normal limits. Computed tomography scan of the brain and orbit showed nasal soft tissue mass with local extension to the left extraconal space. Histopathological examination of the nasal biopsy tissue showed high-grade DLBCL. The distal cranial neuropathy caused by the lymphomatous infiltration of the left paranasal sinuses had preceded the systemic manifestation. The patient was initiated on chemotherapy and has been, at the time of writing, in remission for 8 months after presentation.

Keywords: diffuse large B cell lymphoma, orbital apex syndrome, sinonasal lymphoma

Correspondence: See Teng Tan, MBBS (UM), Department of Ophthalmology, Hospital Tuanku Ja'afar Seremban, Malaysia

E-mail: Ncltan10@gmail.com 


\section{Abstrak}

Limfoma sinonasal adalah bentuk limfoma bukan Hodgkin (NHL) yang jarang dijumpai, melibatkan hanya 1.5\% daripada semua jenis limfoma. Kami melaporkan satu kes sinonasal primer limfoma sel B besar (DLBCL) yang menyebar yang jarang ditemui yang mengiringi sindrom apeks orbital. Seorang lelaki Cina berusia 75 tahun mengalami tahap penglihatan kiri yang semakin menurun selama lebih dari 2 bulan. Dia juga mengadu kerap mengalami rhinorrhea sejak 4 bulan yang lalu. Setelah diperiksa, tahap penglihatan mata kirinya adalah lemah beserta ptosis separa, bengkak kawasan periorbital dan oftalmoplegia. Semua keputusan makmal adalah normal. Imbasan tomografi (CT) otak dan orbit menunjukkan ketumbuhan tisu lembut hidung dengan perebakan setempat ke ruang ekstrakonal kiri. HPE tisu biopsi hidung menunjukkan DLBCL gred tinggi. Neuropati kranial distal yang disebabkan oleh penyusupan limfomatosa sinus paranasal kiri telah mendahului manifestasi sistemik. Pesakit telah dirawat dengan kemoterapi dan kini telah 8 bulan dalam fasa pemulihan.

Kata kekunci: limfoma sel B besar yang tersebar, limfoma sinonasal, sindrom puncak orbital

\section{Introduction}

Approximately $70-80 \%$ of non-Hodgkin lymphomas (NHLs) are nodal lymphomas; the most common extranodal sites involved are the gastrointestinal tract (34\%), followed by head/neck (14\%) and skin (11\%)..$^{1}$ One of the rarest extranodal sites $(0.44 \%)$ is the sinonasal tract. ${ }^{2}$ The prevalence of sinonasal lymphoma is $0.37 \%$ of all extranodal NHL sites. ${ }^{3}$ These tumours are rare in Asia; this is reflected in the scarcity of literature that reviewed outcomes for the Asian cohorts with sinonasal lymphoma.

\section{Case presentation}

In June 2019, we evaluated a 75-year-old Chinese male with a history of hypertension. He experienced progressive visual loss in the left eye and retro-orbital pain for 2 months, accompanied by frequent rhinorrhoea for the past 4 months.

Compared with his right eye, visual acuity in the left eye was markedly reduced (OD 6/12, OS counting fingers). The left pupil showed 4+ relative afferent pupillary defect. The patient also exhibited periorbital fullness, mild proptosis, and incomplete ptosis of the left upper eyelid (Figs. 1 and 2). Left eye motility was limited in upgaze, downgaze, and adduction (Fig. 3). General physical examination was unremarkable. A computerized tomography (CT) scan revealed a soft tissue lesion in the bilateral 


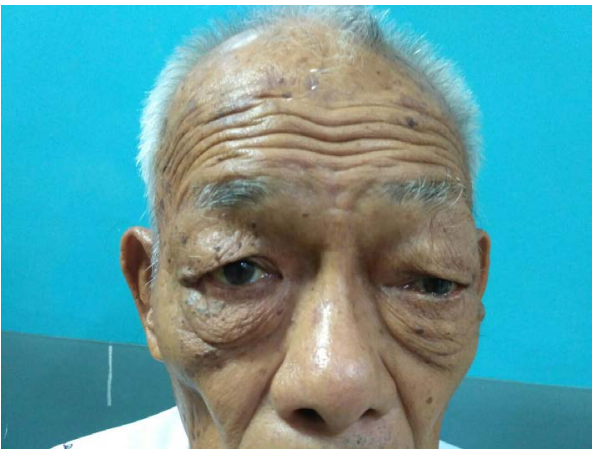

Fig. 1. Left eye fullness and proptosis
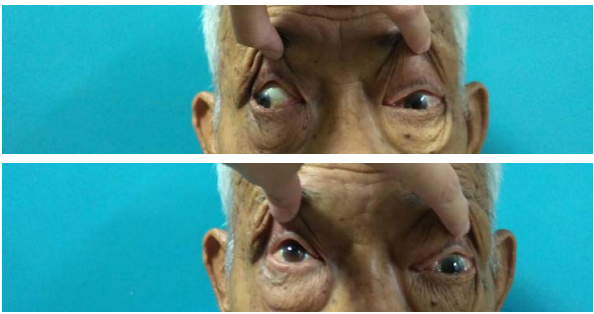

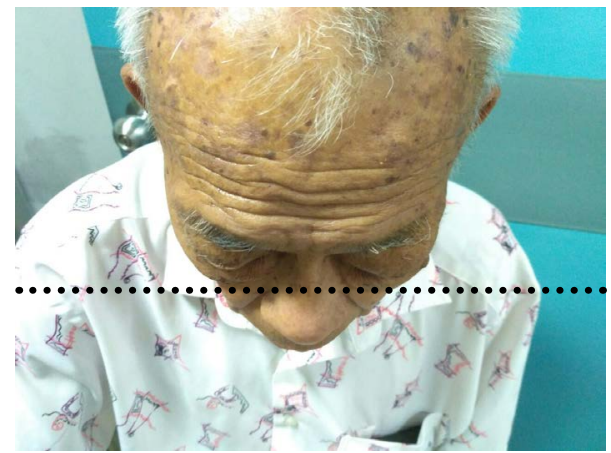

Fig. 2. Clinical Photography in primary position showing ptosis in the patient's left eye.
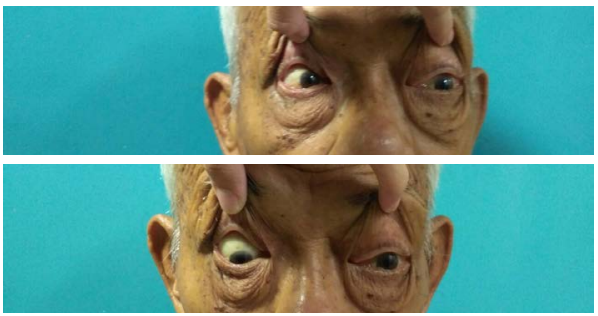

Fig. 3. Four gaze photo of a patient with orbital apex syndrome showing limitation of motility in left eye elevation, depression, abduction and adduction.

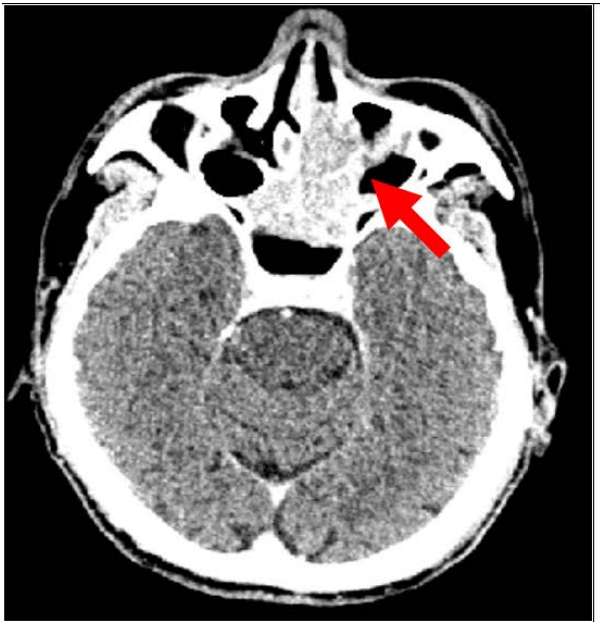

Fig. 4. CT scan showing a soft tissue lesion in the bilateral posterior nasal cavity, ethmoidal, sphenoid and left frontal sinuses extends into left extra-conal space.

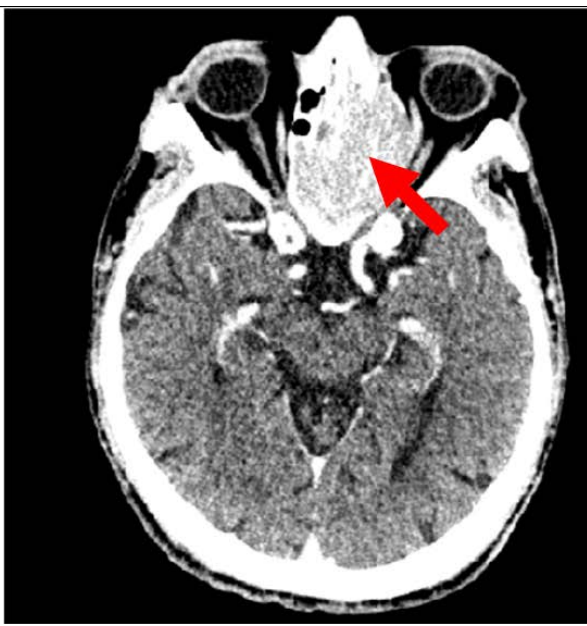

Fig. 5. This mass partially obliterating the left optic canal, displacing left medial rectus muscle. 


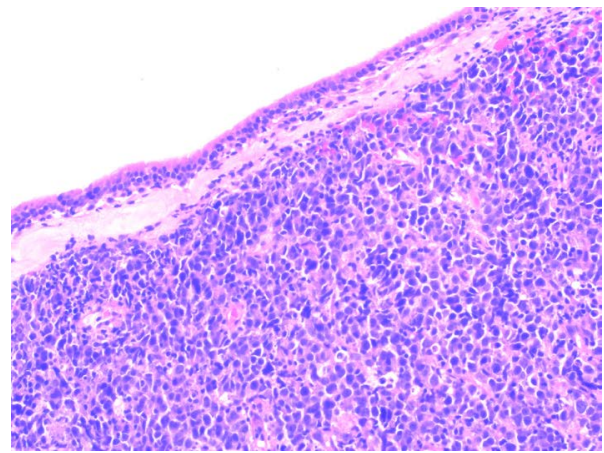

Fig. 6. The hematoxylin and eosin (H\&E x100) stained slides of section from nasal tissue mass showing malignant lymphoid cells exhibiting severe nuclear pleomorphism diffusely infiltrating the tissue.

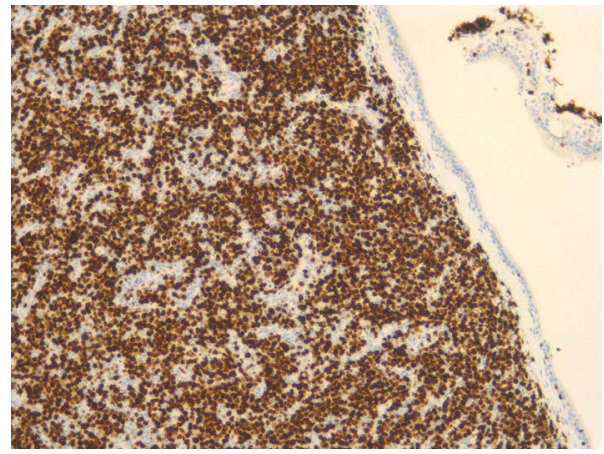

Fig. 8. On immunohistochemistry (IHC) stain showing the lymphoma cells are positive for Ki67; Proliferative index $90 \%$.

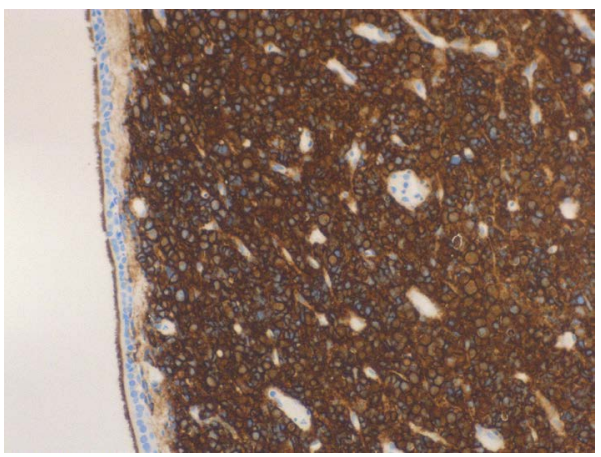

Fig. 7. On immunohistochemistry (IHC) stain showing the lymphoma cells are positive for CD20.

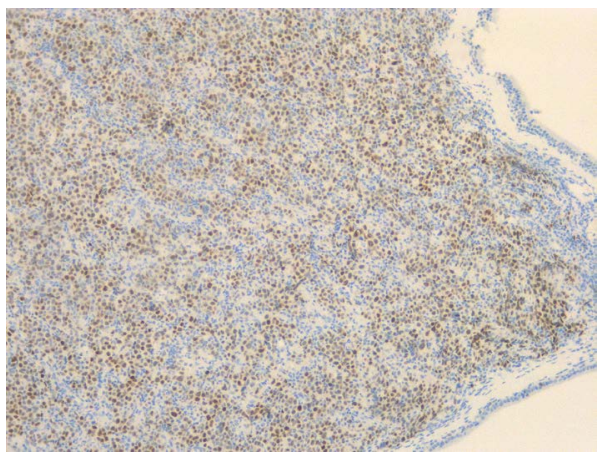

Fig. 9. On immunohistochemistry (IHC) stain showing the lymphoma cells are positive for c-Myc (50\%).

posterior nasal cavity, ethmoidal, sphenoid, and left frontal sinuses extending into the left extraconal space. This mass partially obliterated the left optic canal, displacing the left medial rectus muscle; associated with bony erosion and local extension (Figs. 4 and 5).

The patient was referred to an ENT specialist; diagnostic nasal endoscopic examination and a biopsy were performed. Histopathological findings confirmed the diagnosis of high-grade diffuse large $B$ cell lymphoma (DLBCL). Tumour cells were immunepositive for C-myc, BCL-2, and BCL-6 (Figs 6-9). Staging workup showed no metastases.

The patient received 12 cycles of chemotherapy consisting of R-CHOP regimen 
over 6 months. Visual acuity, ptosis, and ocular motility improved after 6 months, and CT showed a marked reduction of the primary sinonasal tumour with minimal residual lesion within the left nasal cavity and left ethmoid sinus; the rest of the sinuses were clear with unremarkable orbits, optic nerve, and optic canal.

\section{Discussion}

This case report highlights the challenges associated with the diagnosis and treatment of patients with sinonasal DLBCL. Sinonasal DLBCL develops gradually within a confined anatomic space; the initial signs and symptoms are known to be subtle and often mimic those of benign inflammatory diseases. According to Yen et al., the average duration between a patient's awareness of symptoms and their decision to seek medical help was 8.9 months. ${ }^{4}$ Patients tend to ignore their symptoms until alerting symptoms continue to develop, whereby the neoplasm reaches a considerable size or involves the adjacent anatomical structures.

In comparison to T-cell lymphoma, which is mostly diagnosed at an early stage, B-cell lymphoma is usually diagnosed at a late stage. T-cell lymphoma is commonly located in the nasal cavity and results in nasal symptoms earlier, whereas B-cell lymphoma found in sinuses very often induces symptoms only after extension to surrounding structures. ${ }^{4}$ Besides, B-cell lymphoma is usually associated with bone destruction, particularly in the orbital region, frequently causing proptosis and cranial neuropathy.

The bony orbital apex is formed by the optic canal, which comprises the oculomotor nerve (III), trochlear nerve (IV), abducens nerve (VI), and the ophthalmic branch of the trigeminal nerve (V1) in association with optic nerve dysfunction. The damage to these structures results in orbital apex syndrome, as demonstrated in our case.

The primary treatment for nasal DLBCL is chemotherapy; R-CHOP is the standard treatment regimen. Rituximab, a monoclonal anti-CD20 antibody, is known to improve remission rates and overall survival of patients with DLBCL, especially in patients with tumours overexpressing the BCL-2 protein. Our patient was given 12 cycles of R-CHOP and a good outcome was observed.

\section{Conclusion}

Heightened clinical suspicion in any patient with a history of chronic rhinorrhoea in combination with cranial neuropathy or orbital symptoms is vital for early detection and timely management. Chemotherapy with R-CHOP is highly effective, but longer follow-ups are needed. 


\section{Declarations}

Any opinions, findings, conclusions, or recommendations expressed in this material are those of the authors and do not reflect the views of the Ministry of Health Malaysia.

\section{Consent for publication}

The patient provided informed consent for use of his images and clinical data in this case report.

\section{Competing interests}

The authors declare no competing interests regarding the publication of this case report.

\section{Funding}

No funding from an external source supported the publication of this case report.

\section{Acknowledgements}

None to declare.

\section{References}

1. Hao S, Sun Y, Hu C, Zhi Y, Xiao H, Li Y. Primary nasal diffuse large B-cell lymphoma with synchronous pulmonary involvement. Med Baltim. 2019 Apr;98(17): e15439.

2. Steele TO, Rassi EE. Lymphoma of the nasal cavity and paranasal sinuses: A case series. Am J Rhinol. 2016;30(5):5.

3. Cantarella G, Peri A, Goldaniga MC, Gianelli U, Baldini L. B-Cell Nasal Lymphoma Mimicking Hyperplastic Chronic Rhinitis. Otolaryngol Neck Surg. 135(1):165-167.

4. Yen T-T, Wang R-C, Jiang R-S, Chen S-C, Wu S-H, Liang K-L. The diagnosis of sinonasal lymphoma: a challenge for rhinologists. Eur Arch Otorhinolaryngol. 2012 May; 269(5):1463-9. 